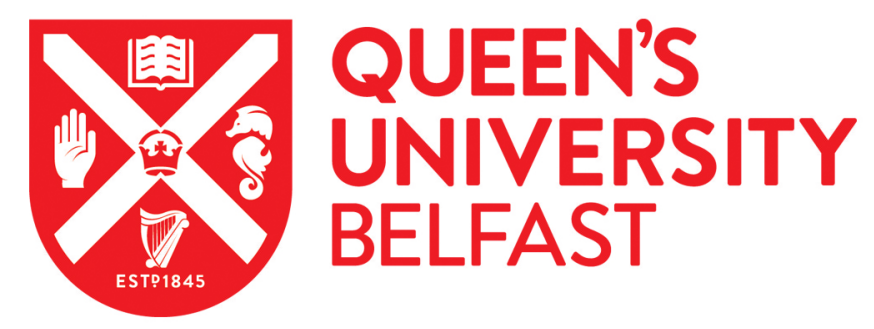

\title{
Biodegradable hydrogels composed of oxime cross-linked poly(ethylene glycol), hyaluronic acid and collagen: a platform for soft tissue engineering
}

Hardy, J. G., Lin, P., \& Schmidt, C. E. (2015). Biodegradable hydrogels composed of oxime cross-linked poly(ethylene glycol), hyaluronic acid and collagen: a platform for soft tissue engineering. Journal of Biomaterials Science, Polymer Edition , 26(3), 143-161. https://doi.org/10.1080/09205063.2014.975393

Published in:

Journal of Biomaterials Science, Polymer Edition

Document Version:

Peer reviewed version

Queen's University Belfast - Research Portal:

Link to publication record in Queen's University Belfast Research Portal

Publisher rights

(C) 2014 Taylor \& Francis.

This is an accepted manuscript of an article published by Taylor \& Francis in Journal of Biomaterials Science, Polymer Edition in 2015, available online: http://wwww.tandfonline.com/10.1080/09205063.2014.975393

\section{General rights}

Copyright for the publications made accessible via the Queen's University Belfast Research Portal is retained by the author(s) and / or other copyright owners and it is a condition of accessing these publications that users recognise and abide by the legal requirements associated with these rights.

Take down policy

The Research Portal is Queen's institutional repository that provides access to Queen's research output. Every effort has been made to ensure that content in the Research Portal does not infringe any person's rights, or applicable UK laws. If you discover content in the

Research Portal that you believe breaches copyright or violates any law, please contact openaccess@qub.ac.uk. 


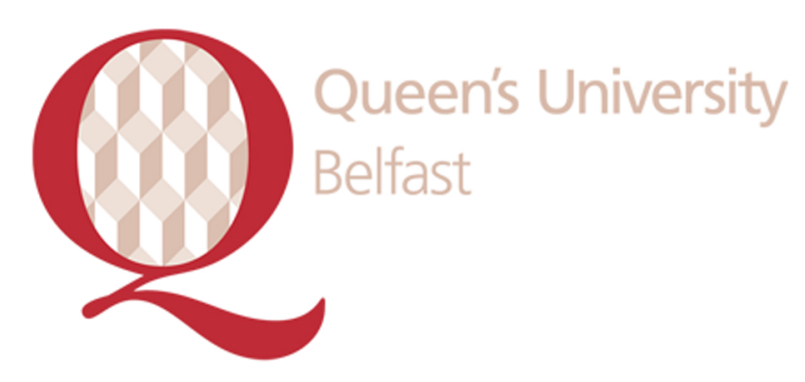

\section{Queen's University Belfast - Research Portal}

\section{Biodegradable hydrogels composed of oxime cross-linked poly(ethylene glycol), hyaluronic acid and collagen: a platform for soft tissue engineering}

Hardy, J. G. (2015). Biodegradable hydrogels composed of oxime cross-linked poly(ethylene glycol), hyaluronic acid and collagen: a platform for soft tissue engineering. Journal of Biomaterials Science, Polymer Edition , 26(3), 143-161. 10.1080/09205063.2014.975393

\section{Published in:}

Journal of Biomaterials Science, Polymer Edition

\section{Link:}

Link to publication record in Queen's University Belfast Research Portal

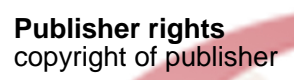

copyright of publisher

\section{General rights}

Copyright for the publications made accessible via the Queens University Belfast Research Portal is retained by the author(s) and / or other copyright owners and it is a condition of accessing these publications that users recognise and abide by the legal requirements associated with these rights.

\section{Take down policy}

The Research Portal is Queens institutional repository that provides access to Queens research output. Every effort has been made to ensure that content in the Research Portal does not infringe any persons rights, or applicable UK laws. If you discover content in the Research Portal that you believe breaches copyright or violates any law, please contact openaccess@qub.ac.uk. 


\section{Biodegradable hydrogels composed of oxime crosslinked poly(ethylene glycol), hyaluronic acid and collagen: a tunable platform for soft tissue engineering}

John G. Hardy, ${ }^{\mathrm{a}, \mathrm{b} *}$ Phillip Lin ${ }^{\mathrm{b}}$ and Christine E. Schmidt ${ }^{\mathrm{a}, \mathrm{b} *}$

a) J. Crayton Pruitt Family Department of Biomedical Engineering, University of Florida, Biomedical Sciences Building JG-53, P.O. Box 116131, Gainesville, FL 32611-6131, United States of America.

b) Department of Biomedical Engineering, The University of Texas at Austin, Austin, TX 78712, United States of America.

*To whom correspondence should be addressed. Tel: 001-352-273-9222; Fax: 001352-273-9221; e-mail: schmidt@bme.ufl.edu Or johnhardyuk@gmail.com

Email addresses:

JGH: johnhardyuk@gmail.com

PL: phillip.lin11@gmail.com

CES: schmidt@bme.ufl.edu

Telephone numbers

CES \& JGH: 001-352-273-9222

PL: 001-281-691-0843 


\title{
Biodegradable hydrogels composed of oxime crosslinked poly(ethylene glycol), hyaluronic acid and collagen: a tunable platform for soft tissue engineering
}

\author{
In situ crosslinking hydrogels are attractive for application as injectable hydrogel- \\ based tissue scaffolds that adapt to fill patient-specific cavities. Oxime click \\ chemistry was used to crosslink hydrogels that were biodegradable, soft, and \\ supportive of cell adhesion. Linear poly(ethylene glycol)s (PEGs, Mn 2 or $4 \mathrm{kDa}$ ) \\ terminated at both ends with aminooxy moieties and hyaluronic acid (HA, Mn 2 \\ $\mathrm{MDa}$ ) derivatives displaying aldehydes were non-toxic towards primary Schwann \\ cells. The PEG and HA derivatives form oxime crosslinked hydrogels with \\ mechanical and swelling properties that were tunable based on the composition \\ of the hydrogels to values analogous to soft tissues such as those found in the \\ central or peripheral nervous system. Gels incorporating collagen-1 supported the \\ adhesion of human mesenchymal stem cells (HMSCs). Such chemistry has the \\ potential to generate clinically relevant injectable hydrogels for minimally \\ invasive personalized medical procedures in the central or peripheral nervous \\ systems.
}

Keywords: Biodegradable; biomaterials; biomimetic mechanical properties; central nervous system; peripheral nervous system; in vitro cell culture; injectable hydrogels; tissue engineering

\section{Introduction}

Hydrogels are an important class of biomaterials that can be used for a variety of biomedical applications such as tissue engineering or drug delivery [1]. In situ crosslinking hydrogels have attracted significant attention for their potential use as injectable tissue scaffolds that adopt the shape of the cavity in which they are injected [2]. Additionally, injectable hydrogels represent useful platforms for the development of patient-specific tissue scaffolds for personalized medicine $[3,4]$.

A variety of chemistries have been investigated for the preparation of in situ gelling hydrogels, including chemical-, enzymatic-, photo-, physical- and 
supramolecular-crosslinking [4]. Each crosslinking methodology has associated advantages and disadvantages (e.g., kinetics and cytotoxicity, respectively). The "click” chemistry philosophy [5] has revolutionized the preparation of polymer-based biomaterials [6, 7]. Click chemistry has been applied to polymers of natural or synthetic origins with many different architectures including linear (e.g., PEG, polysaccharides, proteins), branched (e.g., dendrimers, graft polymers) and macrocyclic polymers [8, 9]. Hawker and co-workers reported seminal early work describing the use of coppercatalyzed click reactions to generate hydrogels with biomedically relevant mechanical properties [10]. The maximum true stress and extension to break were tuned simply and rationally by the molecular weight of the PEG; indeed, variation of the molecular weight of the PEG between 3.4 and $10 \mathrm{kDa}$ allowed the maximum true stress to be tuned between ca. 700 to ca. $2400 \mathrm{kPa}$, and extension to break to be tuned between 400 $\%$ and ca. $1500 \mathrm{kPa}$. A drawback of this methodology is the toxicity of the copper, however this can be removed simply via exhaustive washing with copper chelating agents such as ethylenediaminetetraacetic acid (EDTA) after the gel is formed [10]. A variety of copper-free click reactions were subsequently developed (including strainpromoted azide-alkyne cycloadditions, thiol-ene chemistry, thiol-yne chemistry, DielsAlder reactions, tetrazole-alkene photo-click reactions, tetrazine-nobornene reactions, thiol Michael addition) that circumvent the toxicity of the copper, and these chemistries have been applied to the formation of bulk hydrogels or hydrogel-based beads/particulates which have potential application in either drug delivery or tissue engineering, and are discussed in depth in a number of papers and reviews [11-19].

The various click chemistries have been applied to prepare HA-based hydrogels. Indeed, copper-catalyzed click reactions produced HA hydrogels with elastic moduli in the range of 0.5-4 kPa [20], or HA/gelatin/chondroitin sulphate gels with elastic moduli 
of ca. $7 \mathrm{kPa}$ [21]. Copper-free click reactions have also been used, and thiol-ene chemistry used to produce HA-based micro/nanospheres [22], thiol-yne chemistry between HA and poly(vinylalcohol) to produce hydrogels with storage and loss moduli of ca. $0.6 \mathrm{kPa}$ and $0.1 \mathrm{kPa}$ respectively [23], thiol-nobornene chemistry has been used to generate HA-based hydrogels with elastic moduli in the range of 1-70 kPa [24], and Diels-Alder reactions have been used to generate hydrogels composed of HA and PEG with elastic moduli in the range of 2-110 $\mathrm{kPa}[25,26]$, and thiol Michael addition chemistry has been used to prepare hydrogels composed of HA and PEG with storage and loss moduli of ca. $1 \mathrm{kPa}$ and 10 Pa respectively [27].

The hydrazone [28] and oxime [29-31] bond formation click reactions (between aldehydes or ketones and acylhydrazine or aminooxy derivatives, respectively) are also popular for the preparation of hydrogels. Although this class of "click" reactions are clearly not bioorthogonal (e.g., paraformaldehyde is used to fix cells for histology [32], ketones can react with the $\varepsilon$-amino group of lysine [33], and aminooxy-functionalized tags are used to identify post-translationally-carbonylated proteins in proteomic studies) [34], hydrogels prepared using aldehyde-aminooxy oxime “click” reactions are interesting because the product of the reaction (an oxime) is more stable than Schiff bases formed between either aldehydes or ketones and amines displayed on peptides or proteins in the biological milieu (that yield constitutionally dynamic mixtures of products) $[35,36]$. Such inherently adaptable chemistry can generate in situ crosslinking hydrogels that are clinically relevant soft biomaterials for personalized medicine, and are of interest for application within the nervous system [37-40].

Injectable hydrogels based on polysaccharides and/or PEG derivatives displaying aldehydes and hydrazides reported by the groups of Kohane, Langer, Lowman, Prestwich and Anseth [41-45]. Particularly pertinent examples include those 
from Jia and coworkers who used PEGs terminated with aldehydes and hydrazine functionalized HA to prepare gels with elastic moduli between 100 and $2000 \mathrm{~Pa}$ depending upon the composition of the gels $[46,47]$. We point the interested reader towards excellent reviews on HA-based hydrogels [48-50].

Grover and Maynard reported the concomitant application of aldehydeaminooxy oxime "click" reactions and ketone-aminooxy oxime "click” reactions to prepare injectable soft cell-adhesive PEG-based hydrogels. Aminooxy-terminated PEGs were crosslinked with cytotoxic glutaraldehyde, and rendered cell adhesive via reaction of some of the aminooxy termini with ketone-functionalized peptide derivatives containing the integrin ligand arginine-glycine-aspartic acid (RGD). Interestingly, the cytotoxicity of glutaraldehyde was minimized due to the high reactivity of the aminooxy functional groups towards the aldehydes, and cells were shown to adhere and proliferate on the surface of the gels [29]. Thereafter, Grover and Christman reported the use of analogous chemistry to prepare injectable PEG-, alginate- and HA-based hydrogels for catheter-assisted delivery to the hearts of rats [51]. Becker and co-workers reported the application of ketone-aminooxy oxime "click" reactions to prepare injectable soft PEG-based hydrogels, and subsequently used Huisgen 1,3-cycloaddition and thiol-ene chemistry to pattern them with peptides containing RGD motifs [52], and such substrates have enormous potential for in vitro studies such as high throughput drug screening.

While RGD is commonly used to render non-adhesive materials cell adhesive, there are reports of unintentional side effects of RGD modification (e.g., modifying cell adhesion, spreading, or migration because the RGD motifs are not displayed with biomimetic distributions [53-57]) that may diminish their prospects for clinical translation. We believe that incorporation of cell adhesive proteins such as alpha- 1 type 
collagen (COL-1) will circumvent these problems, because the sequence and spacing of cell adhesive peptide motifs in such proteins are conserved over a variety of species, thereby facilitating normal cell behaviour.

Herein we report the results of our investigations of biodegradable in situ crosslinking hydrogels based on the oxime "click” reaction between linear PEGs terminated at both ends with aminooxy moieties with HA derivatives displaying aldehydes, and optionally, COL-1. With a view to the implantation of the hydrogels via minimally invasive techniques in soft tissues such as those comprising the central and peripheral nervous systems, we assess the toxicity of the PEG and HA derivatives to primary neuroglia (supporting cells of the nervous system), and the mechanical properties of the hydrogels to assure that they are mimetic of human nervous tissues. Insitu crosslinking hydrogels capable of supporting the adhesion of stem cells are being investigated for both drug delivery and tissue engineering [58]. It is conceptually possible to aid neural tissue regeneration and repair via stem cell therapies, which may be able to treat Huntington's disease, Parkinson's disease and other neurological disorders [59-65]. Multipotent HMSCs are a potentially clinically-relevant autologous source of stem cells currently under investigation for a variety of personalized medical devices [66-70], consequently we assessed their adhesion on the hydrogels.

\section{Materials and Methods}

\subsection{Materials}

Unless otherwise stated, all chemicals for chemical synthesis were of ACS grade, purchased from Sigma-Aldrich and used as received without further purification. For cell culture, all reagents were purchased from Invitrogen (Carlsbad, CA) unless 
otherwise noted. Human Mesenchymal Stem Cells (HMSCs) were purchased from Lonza (Gaithersburg, MD).

\subsection{Synthetic and Analytical Methods}

${ }^{1} \mathrm{H}$ and ${ }^{13} \mathrm{C}$ NMR spectra were recorded on a Varian Mercury $400 \mathrm{MHz}$ NMR spectrometer, using residual solvent ${ }^{1} \mathrm{H}$ peaks as internal references for the ${ }^{1} \mathrm{H}$ NMR spectra and the solvent ${ }^{13} \mathrm{C}$ peaks as references for the ${ }^{13} \mathrm{C}$ NMR spectra. The following notation is used for the ${ }^{1} \mathrm{H}$ NMR spectral splitting patterns: singlet (s), doublet (d), multiplet (m), broad (br).

\subsection{Synthesis}

\subsubsection{Synthesis of Phthalimide-Terminated PEGs}

Phthalimide-terminated PEGs were synthesized by adaptation of the literature [71]. To solutions of PEG diols (2 mmol, with average molecular weights of either 2 or $4 \mathrm{kDa}$ ) in $\mathrm{CH}_{2} \mathrm{Cl}_{2}$ was added diisopropylazodicarboxylate (DIAD, $9.6 \mathrm{mmol}$ ), $N$ hydroxyphthalimide (11.2 mmol), and triphenylphosphine $\left(\mathrm{PPh}_{3}, 11.2 \mathrm{mmol}\right)$. The resulting mixture was stirred for $24 \mathrm{~h}$ at room temperature under an atmosphere of argon. Then the reaction mixture was added dropwise to cold diethylether $\left(\mathrm{Et}_{2} \mathrm{O}, 4{ }^{\circ} \mathrm{C}\right)$ that was rapidly stirred, inducing precipitation of the polymers and facilitating their isolation by vacuum filtration. The powders were washed with cold $\mathrm{Et}_{2} \mathrm{O}$ and dried under high vacuum for 48 hours. This process was repeated until ${ }^{1} \mathrm{H}$ NMR in $\mathrm{d}_{6}$-DMSO indicated that the reaction was complete. Phthalimide-terminated PEG-2k was isolated in a yield of 23.5\%, whereas the phthalimide-terminated PEG-4k was isolated in a yield of 82\%. ${ }^{1} \mathrm{H}$ NMR (400 MHz, d6-DMSO): $\delta$ 3.4-3.55 (br m, $\mathrm{CH}_{2} \mathrm{O}, \mathrm{PEG}$ ), 3.7-3.75 (br m, 4H, $\mathrm{CH}_{2} \mathrm{O}, \mathrm{PEG}$ ), 4.25-4.3 (br m, 4H, $\mathrm{CH}_{2} \mathrm{O}, \mathrm{PEG}$ ), 7.86 (br s, 8H, Ar- $\mathrm{H}$, phthalimide). 


\subsubsection{Synthesis of Aminooxy-Terminated PEGs}

Aminooxy-terminated PEGs were synthesized by adaptation of the literature [71]. The phthalimide moieties at the PEG termini were cleaved by the addition of hydrazine hydrate (10 moles of hydrazine hydrate per mole of PEG chains) to solutions of phthalimide-terminated PEGs in dichloromethane. The reaction mixtures were stirred under argon at room temperature for 24 hours, followed by filtration to remove the phthalhydrazide byproduct), followed by evaporation of the volatiles in vacuo. This process was repeated for another 72 hours after which ${ }^{1} \mathrm{H}$ NMR in $\mathrm{d}_{6}$-DMSO indicated that the reaction was complete. Aminooxy-terminated PEG-2k was isolated in a yield of 25\%, whereas the aminooxy-terminated PEG-4k was isolated in a yield of $52 \% .{ }^{1} \mathrm{H}$ NMR (400 MHz, d6 6 -DMSO): $\delta$ 3.45-3.7 (br m, $\mathrm{CH}_{2} \mathrm{O}, \mathrm{PEG}$ ), 5.97 (br s, 4H, $\mathrm{ONH}_{2}$ ).

\subsubsection{Synthesis of Hyaluronic Acids Displaying Aldehydes}

HA-ALDs were synthesized by adaptation of the literature [44]. 1.0 g HA (MW ca. 2 $\mathrm{MDa})$ was dissolved in ultrapure (Millipore) water (100 mL) at a concentration of 10 $\mathrm{mg} \mathrm{mL} \mathrm{m}^{-1}$. Sodium periodate $(0.535 \mathrm{~g}, 2.5 \mathrm{mM})$ was added and the reaction was stirred for 1,2 or 24 hours at room temperature in the dark (to prepare HA-ALD-1, HA-ALD-2 and HA-ALD-24 respectively). Unreacted periodate was quenched by the addition of ethylene glycol (140 $\mu \mathrm{L}, 2.5 \mathrm{mM})$ and the reaction was stirred for 1 hour at room temperature in the dark. Low molecular weight contaminants were removed via exhaustive dialysis against ultrapure water in ready-to-use dialysis sacks (MWCO 3.5 kDa, Spectra/Por ${ }^{\circledR}$, Spectrum Labs, USA), for 4 days with water exchange at least 3 times daily. HA-ALD-1, HA-ALD-2 and HA-ALD-24 were isolated by lyophilization in yields of ca. 50, 40 and $30 \%$ by mass respectively. 


\subsection{Cytotoxicity of PEG and HA Derivatives}

The cytotoxicity of the PEG and HA derivatives towards neonatal rat Schwann cells isolated from sciatic nerves (purchased from ScienCell, Carlsbad, CA) was determined using a Cell Titer-Glo® Luminescent Cell Viability Assay (Promega, USA). Full details are found in Appendix 1.

\subsection{Hydrogel Preparation}

Stock solutions of HA-ALDs (1 wt \% in PBS) and aminooxy-terminated PEGs (0.117 M in PBS) were prepared. Gels were prepared by mixing the various HA-ALDs and aminooxy-terminated PEGs in three different volume ratios (HA-ALDs:aminooxyterminated PEGs): 10:1, 15:1 or 20:1 respectively. Typically, a volume of ca. $150 \mu \mathrm{L}$ of pre-gel solutions was injected into cylindrical molds (with diameters of $9 \mathrm{~mm}$ and heights of $1.7 \mathrm{~mm}$ ) formed by attaching silicone isolators with adhesive on one side (supplied by Grace Bio-Labs, Bend, OR) to glass slides. Optionally, rat tail COL-1 (BD Biosciences) was added at a final concentration of 50, 100 or $200 \mu \mathrm{g} \mathrm{mL} \mathrm{m}^{-1}$ of gel.

\subsection{Fourier Transform Infrared Spectroscopy (FTIR)}

Infrared spectroscopy was carried out on a Thermo Scientific Nicolet 380 FTIR Spectrometer (Thermo Fisher Scientific Inc., USA). Spectra were recorded for 16 scans in ATR mode at $21^{\circ} \mathrm{C}$, with a $1 \mathrm{~cm}^{-1}$ resolution. Spectra were corrected for background and atmosphere using OMNIC software provided with the spectrometer.

\subsection{Hydrogel Swelling and Flory-Rehner Calculations}

The swelling properties of cylindrical gels prepared as described in section 2.5. (i.e., with diameters $9 \mathrm{~mm}$ and heights of $1.7 \mathrm{~mm}$ ) were determined and Flory-Rehner calculations based on these data were carried out in accordance with the literature [7280]. Full details are found in Appendix 1. 


\subsection{Mechanical Testing}

Compressive tests on cylindrical gels prepared as described in section 2.5. (i.e., with diameters $9 \mathrm{~mm}$ and heights of $1.7 \mathrm{~mm}$ ) were performed using an Instron Materials Testing Machine 5543 Series Single Column System (Instron, Norwood, MA) with Bluehill 2 software. Full details are found in Appendix 1.

\subsection{In Vitro Degradation Studies}

Degradation of cylindrical gels prepared as described in section 2.5. (i.e., with diameters $9 \mathrm{~mm}$ and heights of $1.7 \mathrm{~mm}$ ) upon exposure to hyaluronidase (10 $\mathrm{U} \mathrm{mL}^{-1}$ in PBS) was studied over 25 days. Full details are found in Appendix 1.

\subsection{Uronic Acid Quantification Assay}

The quantity of uronic acid released upon degradation of the gels in vitro was assayed using a methodology adapted from the uronic acid carbazole reaction reported by Cesaretti and co-workers [81]. Full details are found in Appendix 1.

\subsection{Cell Culture}

HMSCs were cultured on the hydrogels in under $3 \mathrm{~mm}$ of DMEM supplemented with $10 \%$ fetal bovine serum, $100 \mathrm{U} \mathrm{ml}^{-1}$ penicillin, $100 \mu \mathrm{g} \mathrm{ml}^{-1}$ streptomycin, $0.25 \mu \mathrm{g} \mathrm{ml}^{-1}$ amphotericin, $0.1 \mathrm{mM}$ non-essential amino acids, and $1 \mathrm{ng} \mathrm{ml}^{-1}$ basic fibroblast growth factor. Full details are found in Appendix 1.

\section{Results and Discussion}

\subsection{Polymer Synthesis, Characterization and Cytotoxicity}

Linear aminooxy-terminated PEGs were prepared via adaptation of the methodology described by the Francis group (Scheme 1) [71]. Phthalimide-terminated PEGs (with Mn of ca. 2 or $4 \mathrm{kDa}$ ) were prepared via the reaction of hydroxyl-terminated PEGs with 
N-hydroxyphthalimide, triphenylphosphine (Ph3P) and diisopropyl azodicarboxylate (DIAD), and purified by precipitation. Phthalimide-terminated PEG-2k was isolated in a yield of 23.5\%, whereas the phthalimide-terminated PEG-4k was isolated in a yield of 82\%. ${ }^{1} \mathrm{H}$ NMR recorded in $\mathrm{d}_{6}$-DMSO was used to confirm the quantitative conversion of the hydroxyl-terminated PEG starting materials to the phthalimide-terminated PEGs; with peaks at $\delta 3.4-3.55,3.7-3.75$ and $4.25-4.3$ ppm corresponding to protons on the backbone of the PEG chains and the peak at $\delta 7.86 \mathrm{ppm}$ corresponding to the protons on the aromatic phthalimide group at the termini of the PEG chains.

Exposure of the phthalimide-terminated PEGs to hydrazine cleaved the phthalimide groups and facilitated purification of the aminooxy-terminated PEGs via filtration to remove the phthalhydrazide byproduct, followed by evaporation of the volatiles under vacuum. Aminooxy-terminated PEG-2k was isolated in a yield of 25\%, whereas the aminooxy-terminated PEG-4k was isolated in a yield of 52\%. ${ }^{1} \mathrm{H}$ NMR recorded in $\mathrm{d}_{6}$-DMSO was used to confirm the quantitative conversion of the phthalimide-terminated PEGs to the aminooxy-terminated derivatives; with peaks at $\delta$ 3.45-3.7 ppm corresponding to protons on the backbone of the PEG chains and the peak at $\delta 5.97 \mathrm{ppm}$ corresponding to the protons on the aminooxy group at the termini of the PEG chains.

HA derivatives displaying aldehydes were prepared by adaptation of the methodology reported by the Langer group [44]. HA (Mn of ca. 2 MDa) was exposed to sodium periodate for 1,2 or 24 hours, after which the reaction was quenched with ethylene glycol. The product was purified by dialysis against water and lyophilized. The resulting aldehyde-displaying HA derivatives are hereafter referred to as HA-ALD-1, HA-ALD-2 and HA-ALD-24 depending upon the number of hours to which they were 
exposed to sodium periodate, and were isolated in yields of ca. 50, 40 and $30 \%$ by mass respectively.

In-situ crosslinking hydrogels have potential application in a variety of biomedical technologies, including drug delivery and tissue engineering [1-4]. With a view to the implantation of the in-situ crosslinking hydrogels described herein in neural tissues, we assessed the cytotoxicity of the PEG and HA derivatives towards glial cells from the peripheral nervous system, specifically, primary Schwann cells isolated from neonatal rats in preference to immortalized cell lines. Schwann cells were incubated with various concentrations of PEG and HA derivatives for 24 hours, after which cell viability was assessed using a Cell Titer-Glo® Luminescent Cell Viability Assay, and viability is reported relative to cell adhesive plasma-treated tissue culture plastic (arbitrarily assigned to be $100 \%$ ). Cell viability was high in all cases, but observed to decrease moderately (to ca. $90 \%$ ) at higher concentrations (6 mg mL $\mathrm{m}^{-1}$ ) of the PEG and HA derivatives (Figure 1). The high viabilities of the primary neuroglia suggest that the PEG and HA derivatives described herein are promising building blocks for in-situ crosslinking hydrogels for application as drug delivery devices or tissue scaffolds for the nervous system.

\subsection{Hydrogel Preparation and Physicochemical Characterization}

Hydrogels were formed by mixing stock solutions of the various components in phosphate buffered saline (PBS, pH 7.4) prior to injection into flexible PDMS molds. The gel compositions studied here are presented in Table 1. Crosslinking was observed to occur within seconds of mixing the PEGs and HA-ALD-24, with crosslinking being complete within seconds for the gels incorporating aminooxy-terminated PEG-4k and minutes for the gels incorporating aminooxy-terminated PEG-2k. Such swift crosslinking is ideal for application as either drug delivery devices or tissue scaffolds 
for the nervous system. For consistency, characterization of the gels via various techniques was carried out 24 hours after their formation.

Successful crosslinking of the various aminooxy-terminated PEGs with the aldehyde-functionalized HA derivatives was confirmed by the appearance of a peak at $1672 \mathrm{~cm}^{-1}$ in the infrared absorption spectrum of lyophilized hydrogels, which corresponds to the aliphatic oxime bonds that crosslink the hydrogels [51] (Figure 2).

The combination of various ratios of the PEG and HA derivatives facilitated the development of oxime crosslinked hydrogels with tunable mechanical and swelling properties. The mechanical properties of the resulting hydrogels and the results of the Flory-Rehner calculations based on swelling experiments are presented in Table 1. The mechanical properties of biomaterials are known to play an important role in the way in which cells interact with them both in vitro and in vivo [82-85], therefore the mechanical properties of the hydrogels upon exposure to compressive or shear stress were examined. The compressive moduli, E, of the hydrogels were between 2 to $12 \mathrm{kPa}$, analogous to soft tissues of the nervous system (e.g., brain has a compressive modulus of ca. 0.5 to $10 \mathrm{kPa}$ ) [86-91]. There was no clear trend in the compressive moduli for the gels incorporating low molecular weight (2 kDa) aminooxy-terminated PEG. However, gels incorporating the higher molecular weight (4 kDa) PEG analogue displayed compressive moduli that increased with increasing amounts of PEG, suggesting more efficient crosslinking of the hydrogels. Similar trends were observed for the storage and loss moduli of the hydrogels as assessed via rheology, with gels incorporating the low molecular weight PEG displaying storage moduli of ca. 400 to $600 \mathrm{~Pa}$, and loss moduli of ca. 6 to $24 \mathrm{~Pa}$ (akin to those reported by Grover and Christman [51]), and a selection of other HA-based hydrogels [20-27, 46, 47]; whereas gels incorporating the higher molecular weight PEG displaying storage moduli of ca. 
140 to 2870 Pa (akin to those reported by Collins and Birkinshaw [92] and others [2027, 46, 47]), and loss moduli of ca. 6 to $57 \mathrm{~Pa}$, both of which increased with increasing amounts of PEG (Table 1 and Appendix 1 Figure A1). Importantly, these properties mimic the human nervous system (e.g., human brain has a storage modulus of ca. 1000 to $3100 \mathrm{~Pa}$, and a loss modulus of ca. 400 to $2500 \mathrm{~Pa}$ ) [86-91], and are in the range of other HA-based hydrogels [20-27, 46, 47, 92]. These observations were supported by results from swelling experiments and Flory-Rehner calculations (Table 1). The effective crosslink density, $v_{\mathrm{e}}$, calculated for the hydrogels were ca. $5 \times 10^{-6} \mathrm{~mol} \mathrm{~cm}^{-3}$, and found to increase with increasing amounts of PEG, and, concomitantly, the swollen hydrogel mesh sizes in PBS, $\xi$, calculated for the hydrogels were ca. $2 \mathrm{~nm}$ and found to decrease with increasing amounts of PEG and therefore crosslinking density. These values are consistent with the literature for analogous HA-based hydrogels [76].

Gels formed using HA-ALD-1 or HA-ALD-2 (gels 7-12, Appendix 1, Table A1) gelated more slowly (over the duration of minutes to hours), and tended to have compressive moduli that were lower than those formed using HA-ALD-24, which indicates that the duration of exposure of the HA to the oxidizing reagent (sodium periodate) determines the number of aldehydes generated on the backbone of the HA and thereby the crosslinking density within the gel. It may therefore be possible to tune the mechanical properties of the gels by varying the duration of exposure of the HA to sodium periodate, potentially facilitating the preparation of hydrogels with mechanical properties matching specific soft tissues. For example, this could simply be achieved by quenching the periodate oxidation reaction with ethylene glycol at specific time points (e.g., 1, 3, 12, 24, 48, 72, 96 hours). It would be expected that shorter oxidation times would yield hyaluronic acids displaying fewer aldehyde moieties and generate softer gels, whereas those oxidized for longer periods would yield hyaluronic acids displaying 
more aldehyde moieties (i.e. more sites for crosslinking with aminooxy-terminated PEGs) and generate less flexible gels; further, after very long periods of oxidation the molecular weight of the hyaluronic acid may decrease to the point at which the gels would be weaker (however, this is outside the scope of the present study).

\subsection{In Vitro Degradation and Cell Culture}

It is impossible to accurately reproduce the conditions that materials encounter when implanted in vivo in the laboratory, but in vitro degradation studies are useful to confirm the potential for the gels to degrade upon exposure to enzymes found in vivo. Consequently, gel degradation upon exposure to a high concentration of hyaluronidase (10 $\mathrm{U} \mathrm{mL}^{-1}$ in PBS) was studied over a time period of twenty five days by both mass loss and an assay that quantified the amount of uronic acid released [81]. Mass loss for gels composed of HA-ALD-24 and aminooxy-terminated PEG-2k or PEG-4k derivatives (Figure 3) was observed during the first week and continued over the entire duration of the assay, reaching approximately $40 \%$ loss after 25 days for all of the gel compositions, albeit with no clear trend based upon the crosslinking density. The byproduct of the enzymatic degradation of HA is uronic acid, and the amount released increased as the gels masses were concomitantly found to decrease (Figure 4), and was typically on the $\mu \mathrm{g}$ regime (up to ca. $10 \%$ of the HA content of each gel over the period of the 25 day assay), thereby confirming that enzymatic degradation of the HA in the gel is possible. Furthermore, gels formed using HA-ALD-1 or HA-ALD-2 with the aminooxy-terminated PEG-4k derivative, were observed to degrade more quickly under the same experimental conditions (Appendix 1, Figure A2 and A3); logically, the degradation of these mechanically weaker gels (Appendix 1, Table A1) is related to their lower level of crosslinking, further supporting our suggestion that it may be possible to tailor the properties of the gels to match specific tissues. 
As noted above, researchers are currently investigating the feasibility of stem cell therapies (including multipotent HMSCs as a clinically-relevant autologous source of stem cells) to aid neural tissue regeneration and repair, targeting Huntington's disease, Parkinson’s disease and other neurological disorders [66-70]. Consequently, we prepared hydrogels based on gels 1-6 incorporating various amounts of COL-1 (for precise compositions see Appendix 1, Table A2, gels 13-30) and confirmed the viability of HMSCs adhered on the surface of the after 48 hours of culture. Cells were seeded on gels composed of various ratios of aminooxy-terminated PEGs, HA-ALD-24, and COL1 (Figure 5) exhibited spread morphologies and the cell viability was greater than $88 \%$ for all of the formulations tested (gel-specific values are shown in Figure 6). The high viabilities of the primary HMSCs on the in-situ crosslinking hydrogels described herein suggests that they are promising for application as personalized medical devices within the nervous system.

\section{Conclusion}

In conclusion, we report biodegradable in situ crosslinking hydrogels with biomimetic mechanical properties that are well-suited for application in neural tissues [93-95]. Oxime click chemistry was used to crosslink linear PEGs terminated at both ends with aminooxy moieties and HA derivatives displaying aldehydes. The PEG and HA derivatives were shown to have low cytotoxicities towards primary neuroglia (supporting cells in the peripheral nervous system, namely, Schwann cells). The mechanical and swelling properties were found to be tunable based upon hydrogel composition and mimetic of human nervous tissues. Gels incorporating COL1 supported the adhesion of HMSCs. Such hydrogels have the potential for application as personalized medical devices in the human nervous system, and we foresee their 
application as injectable matrices for peripheral nerve tissue engineering, or indeed as a biodegradable reservoir for a therapeutic (e.g. an anti-inflammatory drug).

\section{Acknowledgements}

We thank the University of Texas at Austin for financial support of Phillip Lin in the form of an Undergraduate Research Fellowship. At the Department of Chemistry at the University of Texas at Austin we thank Prof. Michael J. Krische for access to an IR spectrometer. At the University of Florida we thank Maria K. Villancio-Wolter for assistance with cell counting. This work was supported by the National Science Foundation under Grant Number CBET 1159774; and the National Institute of Health under Grant Number 5R21NS074162-02. We thank the University of Florida for financial support in the form of startup resources.

\section{References:}

1. Slaughter, B. V.; Khurshid, S. S.; Fisher, O. Z.; Khademhosseini, A.; Peppas, N. A., Adv. Mater. 21, 3307 (2009).

2. Rahman, C. V.; Saeed, A.; White, L. J.; Gould, T. W. A.; Kirby, G. T. S.;

Sawkins, M. J.; Alexander, C.; Rose, F. R. A. J.; Shakesheff, K. M., Chem. Mater. 24, 781 (2012).

3. $\quad$ Bae, K. H.; Wang, L. S.; Kurisawa, M., J. Mater. Chem. B 1, 5371 (2013).

4. Van Tomme, S. R.; Storm, G.; Hennink, W. E., Int. J. Pharm. 355, 1 (2008).

5. Barner-Kowollik, C.; Du Prez, F. E.; Espeel, P.; Hawker, C. J.; Junkers, T.; Schlaad, H.; Van Camp, W., Angew. Chem. Int. Ed. 50, 60 (2011).

6. Iha, R. K.; Wooley, K. L.; Nystrom, A. M.; Burke, D. J.; Kade, M. J.; Hawker, C. J., Chem. Rev. 109, 5620 (2009). 
7. O'Reilly, R. K.; Joralemon, M. J.; Hawker, C. J.; Wooley, K. L., New J. Chem. 31, 718 (2007).

8. Lallana, E.; Fernandez-Trillo, F.; Sousa-Herves, A.; Riguera, R.; FernandezMegia, E., Pharm. Res. 29, 902 (2012).

9. Vermonden, T.; Censi, R.; Hennink, W. E., Chem. Rev. 112, 2853 (2012).

10. Malkoch, M.; Vestberg, R.; Gupta, N.; Mespouille, L.; Dubois, P.; Mason, A. F.; Hedrick, J. L.; Liao, Q.; Frank, C. W.; Kingsbury, K.; Hawker, C. J., Chem. Commun. 2774, (2006).

11. Jiang, Y.; Chen, J.; Deng, C.; Suuronen, E. J.; Zhong, Z., Biomaterials. 35, 4969 (2014).

12. Lowe, A. B.; Hoyle, C. E.; Bowman, N. C., J. Mater. Chem., 20, 4745, (2010).

13. van Dijk, M.; Rijkers, D. T. S.; Liskamp, R. M. J. Nostrum, van Noostrum, Hennink, H. E., Bioconj. Chem., 20 (11), 2001 (2009).

14. Nimmo, C. M.; Shoichet, M. S., Bioconj. Chem., 22, 2199, (2011).

15. Alge, D. L.; Azagarsamy, M. A.; Donohue, D. F.; Anseth, K. S., Biomacromolecules, 14, 949 (2013).

16. Yigit, S.; Sanyal, R.; Sanyal, A., Chem. Asian J., 6, 2648, (2011).

17. Ulinuc, A.; Popa, M.; Hamaide, T.; Dobromir, M. Cellulose Chem. Technol., 46 (1-2), 1 (2012)

18. Sun, J.; Tan, H., Materials, 6, 1285 (2013).

19. Elchinger, P. H.; Faugeras, P.A.; Boëns, B.; Brouillette, F.; Montplaisir, D.; Zerrouki, R.; Lucas, R., Polymers, 3, 1607 (2011).

20. Piluso, S.; Hiebl, B.; Gorb, S. N.; Kovalev, A.; Lendlein, A., Neffe, A. T., Int. J. Artif. Organs, 34 (2): 192 (2011).

21. Hua, X.; Li, D.; Zhou, F.; Gao, C., Acta Biomaterialia, 7, 1618 (2011). 
22. Hachet, E.; Sereni, N.; Pignot-Paintrand, I.; Ravaine, R.; Szarpak-Jankowska, A.; Auzély-Velty, R., J. Coll. Int. Sci., 419, 52 (2014).

23. Li, Y.; Wang, L.; Wu, J.; Ma, Y.; Wang, J.; Wang, Y.; Luo, Y., Mater. Lett., 134, 9, (2014).

24. Gramlich, W. M.; Kim, I. L.; Burdick, J. A., Biomaterials, 34, 9803 (2013).

25. Owen, S. C.; Fisher, S. A.; Tam, R. Y.; Nimmo, C. M.; Shoichet, M. S., Langmuir, 29, 7393 (2013).

26. Yu, F.; Cao, X.; Li, Y.; Zeng, L.; Yuan, B.; Chen, F., Polym. Chem., 5, 1082 (2014)

27. Jin, R.; Moreira Teixeira, L. S.; Krouwels, A.; Dijkstra, P. J.; van Blitterswijk, C. A.; Karperien, M.; Feijen, J., Acta Biomaterialia, 6 (6), 1968 (2010).

28. Ganguly, T.; Kasten, B. B.; Bucar, D. K.; MacGillivray, L. R.; Berkman, C. E.; Benny, P. D., Chem. Commun. 47, 12846 (2011).

29. Grover, G. N.; Lam, J.; Nguyen, T. H.; Segura, T.; Maynard, H. D., Biomacromolecules 13, 3013 (2012).

30. Novoa-Carballal, R.; Muller, A. H. E., Chem. Commun. 48, 3781 (2012).

31. Ulrich, S.; Boturyn, D.; Marra, A.; Renaudet, O.; Dumy, P., Chem. Eur. J., 20, 34 (2014).

32. Thavarajah, R.; Mudimbaimannar, V. K.; Elizabeth, J.; Rao, U. K.;

Ranganathan, K., J. Oral Maxillofac. Pathol. 16, 400 (2012).

33. Dalle-Donne, I.; Carini, M.; Orioli, M.; Vistoli, G.; Regazzoni, L.; Colombo, G.; Rossi, R.; Milzani, A.; Aldini, G., Free Radical Bio. Med. 46, 1411 (2009).

34. Hahne, H.; Neubert, P.; Kuhn, K.; Etienne, C.; Bomgarden, R.; Rogers, J. C.; Kuster, B., Anal. Chem. 84, 3716 (2012). 
35. Corbett, P. T.; Leclaire, J.; Vial, L.; West, K. R.; Wietor, J. L.; Sanders, J. K.

M.; Otto, S., Chem. Rev. 106, 3652 (2006).

36. Lehn, J. M., Chem. Soc. Rev. 36, 151 (2007).

37. Schmidt, C. E.; Leach, J. B., Annu. Rev. Biomed. Eng. 5, 293 (2003).

38. Z Zhong, Y. H.; Bellamkonda, R. V., J. R. Soc. Interface 5, 957 (2008).

39. Bellamkonda, R. V.; Pai, S. B.; Renaud, P., MRS Bull. 37, 557 (2012).

40. Webster, R.; Didier, E.; Harris, P.; Siegel, N.; Stadler, J.; Tilbury, L.; Smith, D., Drug Metab. Dispos. 35, 9 (2007).

41. Hudson, S. P.; Langer, R.; Fink, G. R.; Kohane, D. S., Biomaterials 31, 1444 (2010).

42. Vercruysse, K. P.; Marecak, D. M.; Marecek, J. F.; Prestwich, G. D., Bioconjugate Chem. 8, 686 (1997).

43. Prestwich, G. D.; Marecak, D. M.; Marecek, J. F.; Vercruysse, K. P.; Ziebell, M. R., J. Control. Release 53, 93 (1998).

44. Jia, X. Q.; Burdick, J. A.; Kobler, J.; Clifton, R. J.; Rosowski, J. J.; Zeitels, S. M.; Langer, R., Macromolecules 37, 3239 (2004).

45. McKinnon, D. D.; Domaille, D. W.; Cha, J. N.; Anseth, K. S., Adv. Mater. 26, 865 (2014)

46. Jia, X.; Yeo, Y.; Clifton, R. J.; Jiao, T.; Kohane, D. S.; Kobler, J.B.; Zeitels, S.

M.; Langer, R., Biomacromolecules, 7, 3336 (2006)

47. Jha, A. K.; Hule, R. A.; Jiao, T.; Teller, S. S.; Clifton, R. J.; Duncan, R. L.; Pochan, D. J.; Jia, X., Macromolecules, 42, 537 (2009)

48. Prestwich, G. D.; Kuo, J. W., Curr. Pharm. Biotechnol., 9, 242 (2008)

49. Burdick, J. A.; Prestwich, G. D., Adv. Healthcare Mater., 23, H41 (2011).

50. Collins, M.N.; Birkinshaw, C., Carbohydr. Polym., 92 (2), 1262 (2013) 
51. Grover, G. N.; Braden, R. L.; Christman, K. L., Adv. Mater. 25, 2937 (2013).

52. Lin, F.; Yu, J. Y.; Tang, W.; Zheng, J. K.; Defante, A.; Guo, K.; Wesdemiotis,

C.; Becker, M. L., Biomacromolecules 14, 3749 (2013).

53. Maheshwari, G.; Brown, G.; Lauffenburger, D. A.; Wells, A.; Griffith, L. G., J. Cell Sci. 113, 1677 (2000).

54. Kim, J. P.; Zhang, K.; Kramer, R. H.; Schall, T. J.; Woodley, D. T., J. Inv. Dermatol. 98, 764 (1992).

55. Cavalcant-Adam, E. A.; Volberg, T.; Micoulet, A.; Kessler, H.; Geiger, B.; Spatz, J. P., Biophys. J. 92, 2964 (2007).

56. Selheuber-Unkei, C.; Erdmann, T.; Lopez-Garcia, M.; Kessler, H.; Schwartz, U. S.; Spatz, J. P., Biophys. J. 98, 543 (2010).

57. Huang, J.; Grater, S. V.; Corbellini, F.; Rinck-Jahnke, S.; Bock, E.; Kemkemer, R.; Kessler, H.; Ding, J.; Spatz, J. P., Nano Lett.. 9, 1111 (2009).

58. Alvarado-Velez, M.; Pai, S. B.; Bellamkonda, R. V., IEEE T. Bio-Med. Eng. 61, $1474(2014)$.

59. Dooley, D.; Vidal, P.; Hendrix, S., Pharmacol. Therapeut. 141, 21 (2014).

60. Yang, N.; Wernig, M., Nat. Med. 19, 1580 (2013).

61. Kim, S. U., Cell Transplantation 21, 784 (2012).

62. Kim, S. U., Stem Cell Rev. Rep. 7, 130 (2011).

63. Rossi, F.; Cattaneo, E., Nat Rev Neurosci 3, 401 (2002).

64. Ourednik, V.; Ourednik, J.; Park, K. I.; Snyder, E. Y., Clin. Genet. 56, 267 (1999).

65. Grade, S.; Bernardino, L.; Malva, J. O., Int. J. Devl. Neuroscience 31, 692 (2013).

66. Patel, A. N.; Genovese, J., Stem Cells Cloning 4, 61 (2011). 
67. Li, Y.; Liu, M.; Yan, Y.; Yang, S-H., World J. Stem Cells 6, 11 (2014).

68. de Souza Lucena, E. E.; Guzen, F. P.; de Paiva Cavalcanti, J. R. L.; Barboza, C. A. G.; do Nascimento Junior, E. S.; de Sousa Cavalcante, J., J. Oral Maxillofac. Surg. 72, 1001 (2014).

69. $\quad$ Xiong, Y.; Qu, C.; Mahmood, A.; Liu, Z.; Ning, R.; Li, Y.; Kaplan, D. L.; Schallert, T.; Chopp, M., Brain Res. 1263, 183 (2009).

70. Qu, C.; Mahmood, A.; Liu, X. S..; Xiong, Y.; Wang, L.; Wu, H.; Li, B.; Zhang, Z. G.; Kaplan, D. L.; Chopp, M.., Brain Res. 1371, 129 (2011).

71. Schlick, T. L.; Ding, Z. B.; Kovacs, E. W.; Francis, M. B., J. Am. Chem. Soc. 127, 3718 (2005).

72. Marsano, E.; Gagliardi, S.; Ghioni, F.; Bianchi, E., Polymer 41, 7691 (2000).

73. Flory, P. J., Principles of Polymer Chemistry. Cornell University Press: Ithaca, NY, 1953.

74. Metters, A. T.; Anseth, K. S.; Bowman, C. N., Biomed. Sci. Instrum. 35, 33 (1999).

75. Lee, Y.; Kim, D. N.; Choi, D.; Lee, W.; Park, J.; Koh, W. G., Polym. Advan. Technol. 19, 852 (2008).

76. Collins, M. N.; Birkinshaw, C., J. Appl. Polym. Sci., 109, 923 (2008).

77. Cleland, R. L.; Wang, J. L., Biopolymers 9, 799 (1970).

78. Cleland, R. L., Biopolymers 9, 811 (1970).

79. Lowman, A. M.; Peppas, N. A., Hydrogels. In Encyclopedia of Controlled Drug Delivery, Mathiowitz, E., Ed. Wiley: New York, 1999; pp 397-418.

80. de Jong, S. J.; van Eerdenbrugh, B.; von Nostrum, C. F.; Kettenes-van den Bosch, J. J.; Hennink, W. E., J. Control. Release 71, 261 (2001). 
81. Cesaretti, M.; Luppi, E.; Maccari, F.; Volpi, N., Carbohyd. Polym. 54, 59 (2003).

82. Trappmann, B.; Gautrot, J. E.; Connelly, J. T.; Strange, D. G. T.; Li, Y.; Oyen, M. L.; Stuart, M. A. C.; Boehm, H.; Li, B. J.; Vogel, V.; Spatz, J. P.; Watt, F. M.; Huck, W. T. S., Nat. Mater. 11, 642 (2012)

83. Trappmann, B.; Gautrot, J. E.; Connelly, J. T.; Strange, D. G. T.; Li, Y.; Oyen, M. L.; Stuart, M. A. C.; Boehm, H.; Li, B. J.; Vogel, V.; Spatz, J. P.; Watt, F. M.; Huck, W. T. S., Nat. Mater. 11, 742 (2012).

84. Murphy, C. M.; Matsiko, A.; Haugh, M. G.; Gleeson, J. P.; O'Brien, F. J., J. Mech. Behav. Biomed. 11, 53 (2012).

85. Ayala, R.; Zhang, C.; Yang, C.; Hwang, Y.; Aung, A.; Shroff, S. S.; Arce, F. T.; Lal, R.; Arya, G.; Varghese, S., Biomaterials 32, 3700 (2011).

86. Bilston, L. E., Neural Tissue Biomechanics. Springer: Randwick, Australia, 2011; Vol. 3.

87. Tamura, A.; Hayashi, S.; Watanabe, I.; Nagayama, K.; Matsumoto, T., J. Biomech. Sci. Eng. 2, 115 (2007).

88. Taylor, Z.; Miller, K., J. Biomech. 37, 1263 (2004).

89. Jin, X.; Zhu, F.; Mao, H. J.; Shen, M.; Yang, K. H., J. Biomech. 46, 2795 (2013).

90. Green, M. A.; Bilston, L. E.; Sinkus, R., NMR Biomed. 21, 755 (2008).

91. Klatt, D.; Hamhaber, U.; Asbach, P.; Braun, J.; Sack, I., Phys. Med. Biol. 52, 7281 (2007).

92. Collins, M.N., Birkinshaw, C., J. Mater. Sci. Mater. Med., 19 (11), 3335 (2008).

93. Leipzig, N. D.; Shoichet, M. S., Biomaterials 30, 6867 (2009). 
94. Teixeira, A. I.; Ilkhanizadeh, S.; Wigenius, J. A.; Duckworth, J. K.; Inganas, O.; Hermanson, O., Biomaterials 30, 4567 (2009).

95. Saha, K.; Keung, A. J.; Irwin, E. F.; Li, Y.; Little, L.; Schaffer, D. V.; Healy, K. E., Biophys. J. 95, 4426 (2008). 
Table 1. Compositions and Properties of Hydrogels Composed of HA-ALD-24 and Aminooxy-Terminated PEGs.

\begin{tabular}{|c|c|c|c|c|c|c|}
\hline Parameter & Gel 1 & Gel 2 & Gel 3 & Gel 4 & Gel 5 & Gel 6 \\
\hline $\begin{array}{l}\text { Volume ratio of stock solutions } \\
\text { (HA:PEG) }\end{array}$ & $1: 10$ & $1: 15$ & $1: 20$ & $1: 10$ & $1: 15$ & $1: 20$ \\
\hline Mass of HA-ALD-24 (mg) & 1.4 & 1.5 & 1.4 & 1.4 & 1.5 & 1.4 \\
\hline Mass of $2 \mathrm{kDa} \mathrm{PEG}-\mathrm{ONH}_{2}(\mathrm{mg})$ & 3.28 & 2.34 & 1.64 & 0 & 0 & 0 \\
\hline Mass of 4 kDa PEG-ONH $2(m g)$ & 0 & 0 & 0 & 7.54 & 5.38 & 3.77 \\
\hline CM, E (Pa) & $\begin{array}{l}3383 \pm \\
678\end{array}$ & $\begin{array}{l}2975 \pm \\
1338\end{array}$ & $\begin{array}{l}3406 \pm \\
1905\end{array}$ & $\begin{array}{l}12191 \pm \\
1588\end{array}$ & $\begin{array}{l}5438 \pm \\
1043\end{array}$ & $\begin{array}{l}2300 \pm \\
1041\end{array}$ \\
\hline $\mathrm{SM}, \mathrm{G}^{\prime}(\mathrm{Pa})$ & $\begin{array}{l}594 \pm \\
196\end{array}$ & $407 \pm 27$ & $417 \pm 13$ & $\begin{array}{l}2871 \pm \\
130\end{array}$ & $\begin{array}{l}407 \pm \\
38\end{array}$ & $\begin{array}{l}140 \pm \\
36\end{array}$ \\
\hline LM, G” (Pa) & $24 \pm 19$ & $17 \pm 7$ & $6 \pm 4$ & $57 \pm 11$ & $18 \pm 7$ & $6 \pm 2$ \\
\hline $\begin{array}{l}\text { Mass-weighted average density } \\
\text { of solids, } \rho_{\mathrm{p}},\left(\mathrm{g} \mathrm{cm}^{-3}\right)\end{array}$ & 1.130 & 1.133 & 1.135 & 1.128 & 1.129 & 1.130 \\
\hline$\rho_{\mathrm{p}} / \rho_{\mathrm{s}}$ & 1.130 & 1.133 & 1.135 & 1.128 & 1.129 & 1.130 \\
\hline $\begin{array}{l}\text { Mass-weighted average specific } \\
\text { volume of solids, } \bar{v},\left(\mathrm{~cm}^{3} \mathrm{~g}^{-1}\right)\end{array}$ & 0.884 & 0.883 & 0.881 & 0.886 & 0.885 & 0.884 \\
\hline $\begin{array}{l}\text { Mass-weighted average } \\
\text { polymer-solvent interaction, } \chi\end{array}$ & 0.4870 & 0.4855 & 0.4842 & 0.4886 & 0.4880 & 0.4873 \\
\hline $\begin{array}{l}\text { Composition dependent } \sqrt{\overline{\mathrm{r}}_{O}{ }^{2}} \\
(\mathrm{~nm})\end{array}$ & 18.82 & 24.13 & 31.23 & 17.10 & 19.52 & 21.90 \\
\hline EWC (\%) & $\begin{array}{l}92.8 \pm \\
3.0\end{array}$ & $\begin{array}{l}93.8 \pm \\
0.9\end{array}$ & $\begin{array}{l}94.9 \pm \\
0.8\end{array}$ & $\begin{array}{l}93.5 \pm \\
1.5\end{array}$ & $\begin{array}{l}93.7 \pm \\
1.7\end{array}$ & $\begin{array}{l}95.0 \pm \\
1.2\end{array}$ \\
\hline Swelling ratio based on mass, & $16.8 \pm$ & $16.5 \pm$ & $19.9 \pm$ & $16.0 \pm$ & $16.9 \pm$ & $21.0 \pm$ \\
\hline
\end{tabular}




\begin{tabular}{|c|c|c|c|c|c|c|}
\hline $\mathrm{Q}_{\mathrm{M}}$ & 8.2 & 2.5 & 2.7 & 3.5 & 3.7 & 4.7 \\
\hline Volumetric swelling ratio, $\mathrm{QV}_{\mathrm{V}}$ & $\begin{array}{l}18.9 \pm \\
9.3\end{array}$ & $\begin{array}{l}18.5 \pm \\
2.9\end{array}$ & $\begin{array}{l}22.5 \pm \\
3.1\end{array}$ & $\begin{array}{l}18.0 \pm \\
3.9\end{array}$ & $\begin{array}{l}18.9 \pm \\
4.2\end{array}$ & $\begin{array}{l}23.6 \pm \\
5.4\end{array}$ \\
\hline $\begin{array}{l}\text { Average molecular weight } \\
\text { between crosslinks, } \overline{M_{C}} \times 10^{5}(\mathrm{~g} \\
\left.\mathrm{mol}^{-1}\right)\end{array}$ & $2.3 \pm 1.8$ & $1.9 \pm 0.5$ & $2.4 \pm 0.5$ & $\begin{array}{l}2.3 \pm \\
0.8\end{array}$ & $\begin{array}{l}2.3 \pm \\
0.8\end{array}$ & $\begin{array}{l}3.2 \pm \\
1.2\end{array}$ \\
\hline $\begin{array}{l}\text { Effective crosslink density, } v_{\mathrm{e}} \mathrm{X} \\
10^{-6}\left(\mathrm{~mol} \mathrm{~cm}^{-3}\right)\end{array}$ & $8.1 \pm 5.2$ & $6.4 \pm 1.5$ & $5.0 \pm 1.3$ & $\begin{array}{l}5.7 \pm \\
2.1\end{array}$ & $\begin{array}{l}5.6 \pm \\
2.7\end{array}$ & $\begin{array}{l}4.0 \pm \\
1.6\end{array}$ \\
\hline $\begin{array}{l}\text { Root-mean square distance } \\
\text { between crosslinks } \sqrt{\overline{\mathrm{r}}_{O}^{2}}(\mathrm{~nm})\end{array}$ & $0.7 \pm 0.5$ & $0.6 \pm 0.2$ & $0.8 \pm 0.2$ & $\begin{array}{l}0.7 \pm \\
0.2\end{array}$ & $\begin{array}{l}0.7 \pm \\
0.3\end{array}$ & $\begin{array}{l}0.9 \pm \\
0.3\end{array}$ \\
\hline $\begin{array}{l}\text { Swollen hydrogel mesh size in } \\
\text { PBS, } \xi(n m)\end{array}$ & $2.2 \pm 1.5$ & $2.1 \pm 0.6$ & $2.5 \pm 0.6$ & $\begin{array}{l}2.2 \pm \\
0.8\end{array}$ & $\begin{array}{l}2.2 \pm \\
0.8\end{array}$ & $\begin{array}{l}2.7 \pm \\
1.0\end{array}$ \\
\hline
\end{tabular}

Masses reported are dissolved in PBS $(150 \mu \mathrm{L})$. Compressive modulus (CM). Storage modulus (SM) and loss modulus (LM) (G' and G'” respectively) are reported at $1 \mathrm{~Hz}$. 


\section{Figure Captions}

Scheme 1. Synthesis of aminnooxy-terminated PEGs and HA-aldehydes, and their combination to form oxime cross-linked hydrogels. Conditions: a) DIAD, Nhydroxyphthalimide, $\mathrm{PPh}_{3}$; b) hydrazine; c) sodium periodate, ethylene glycol.

Figure 1. Neonatal Schwann cell viability after incubation with PEG and HA derivatives as assessed using a Cell Titer-Glo® Luminescent Cell Viability Assay. Black bars: 0.3 $\mathrm{mg} \mathrm{mL} \mathrm{m}^{-1}$. Dark grey bars: $1.5 \mathrm{mg} \mathrm{mL}^{-1}$. Light grey bars: $3.0 \mathrm{mg} \mathrm{mL}^{-1}$. White bars: 6.0 $\mathrm{mg} \mathrm{mL} \mathrm{m}^{-1}$.

Figure 2. FTIR Spectra. A) Aminooxy-Terminated PEG-4kDa. B) HA-ALD-24. C) Lyophilized oxime crosslinked hydrogel 4.

Figure 3. The results of gel degradation assays upon exposure of gels 1-6 to hyaluronidase (10 U/mL in PBS). A) Mass loss assay for gels composed of HA-ALD24 and aminooxy-terminated PEG2k. Gel 1, black circles, continuous black error bars. Gel 2, grey circles, continuous grey error bars. Gel 3, white circles with black edges, dashed black error bars. B) Mass loss assay for gels composed of HA-ALD-24 and aminooxy-terminated PEG4k. Gel 4, black circles, continuous black error bars. Gel 5, grey circles, continuous grey error bars. Gel 6, white circles with black edges, dashed black error bars.

Figure 4. The results of gel degradation assays upon exposure of gels 1-6 to hyaluronidase (10 U/mL in PBS). A) Uronic acid release assay for gels composed of HA-ALD-24 and aminooxy-terminated PEG2k. Gel 1, black circles, continuous black error bars. Gel 2, grey circles, continuous grey error bars. Gel 3, white circles with black edges, dashed black error bars. B) Uronic acid release assay for gels composed of HA-ALD-24 and aminooxy-terminated PEG4k. Gel 4, black circles, continuous black error bars. Gel 5, grey circles, continuous grey error bars. Gel 6, white circles with black edges, dashed black error bars.

Figure 5. Hydrogels composed of various ratios of aminooxy-terminated PEGs, HAALD-24, and COL1 support HMSC adhesion and survival. Cells were stained with a LIVE/DEAD® Viability/Cytotoxicity Kit for mammalian cells, live cells were stained green with calcein AM, dead cells were stained red with ethidium homodimer. A, B, C) 
Gel 1 with 50, 100 or $200 \mu \mathrm{g} \mathrm{mL}^{-1}$ COL-1 respectively. D, E, F) Gel 2 with 50, 100 or $200 \mu \mathrm{g} \mathrm{mL} \mathrm{mL}^{-1}$ COL-1 respectively. G, H, I) Gel 3 with 50, 100 or $200 \mu \mathrm{g} \mathrm{mL}^{-1}$ COL-1 respectively. J, K, L) Gel 4 with 50, 100 or $200 \mu \mathrm{g} \mathrm{mL}^{-1}$ COL-1 respectively. M, N, O) Gel 5 with 50, 100 or $200 \mu \mathrm{g} \mathrm{mL}^{-1}$ COL-1 respectively. P, Q, R) Gel 6 with 50, 100 or $200 \mu \mathrm{g} \mathrm{mL}^{-1}$ COL-1 respectively. Scale bar represents $100 \mu \mathrm{m}$.

Figure 6. HMSC viability on the gels of various compositions as determined with a LIVE/DEAD ${ }^{\circledR}$ Viability/Cytotoxicity Kit for mammalian cells. Black bars: $50 \mu \mathrm{g} \mathrm{mL^{-1 }}$ COL-1. Dark grey bars: $100 \mu \mathrm{g} \mathrm{mL}^{-1}$ COL-1. White bars: $200 \mu \mathrm{g} \mathrm{mL}^{-1} \mathrm{COL}-1$.

\section{Appendix 1 Figure Captions}

Figure A1. Response of the gels to shear stress as assessed via rheology. Shear modulus, G', hollow shapes. Loss modulus, G', filled shapes. A) HA-ALD-24 and PEG2k. Black circles: gel 1. Blue squares: gel 2. Red triangles: gel 3. B) HA-ALD-24 and PEG4k. Black circles: gel 4. Blue squares: gel 5. Red triangles: gel 6.

Figure A2. The results of gel degradation assays upon exposure of gels 7-12 to hyaluronidase (10 U/mL in PBS). A) Mass loss assay for gels composed of HA-ALD-1 and aminooxy-terminated PEG4k. Gel 7, black circles. Gel 8, grey circles. Gel 9, white circles with black edges. B) Mass loss assay for gels composed of HA-ALD-2 and aminooxy-terminated PEG4k. Gel 10, black circles. Gel 11, grey circles. Gel 12, white circles with black edges.

Figure A3. The results of gel degradation assays upon exposure of gels 7-12 to hyaluronidase (10 U/mL in PBS). A) Uronic acid release assay for gels composed of HA-ALD-1 and aminooxy-terminated PEG4k. Gel 7, black circles. Gel 8, grey circles.

Gel 9, white circles with black edges. B) Uronic acid release assay for gels composed of HA-ALD-2 and aminooxy-terminated PEG4k. Gel 10, black circles. Gel 11, grey circles. Gel 12, white circles with black edges. 


\section{Biodegradable hydrogels composed of oxime crosslinked poly(ethylene glycol), hyaluronic acid and collagen: a tunable platform for soft tissue engineering}

John G. Hardy, ${ }^{\mathrm{a}, \mathrm{b} *}$ Phillip Lin ${ }^{\mathrm{b}}$ and Christine E. Schmidtt ${ }^{\mathrm{a}, \mathrm{b} *}$

\section{Appendix 1}

\section{Materials and Methods}

\section{Materials}

Unless otherwise stated, all chemicals for chemical synthesis were of ACS grade, purchased from Sigma-Aldrich and used as received without further purification. For cell culture, all reagents were purchased from Invitrogen (Carlsbad, CA) unless otherwise noted. Human Mesenchymal Stem Cells (HMSCs) were purchased from Lonza (Gaithersburg, MD).

\section{Cytotoxicity of PEG and HA Derivatives}

Neonatal rat Schwann cells isolated from sciatic nerves were purchased from ScienCell (Carlsbad, CA). Cells were grown on tissue culture plastic and maintained in high glucose DMEM medium supplemented with $10 \%$ fetal bovine serum, $10 \mu \mathrm{g} \mathrm{ml}^{-1}$ bovine pituitary extract (Invitrogen, Carlsbad, CA), and $2 \mu \mathrm{M}$ forskolin (Sigma-Aldrich, St. Louis, MO). To maintain consistent phenotype and cell purity, only cultures between passages 4-8 were used for experiments and purification was confirmed at $>90 \%$ with S100 staining. Cultures reaching 80\% confluency were detached with $0.25 \%$ TrypsinEDTA for 2 min, centrifuged at 800 rpm for 4 min, resuspended in fresh medium, and seeded onto new tissue culture plastic. Medium was changed every third day and kept at 
$37^{\circ} \mathrm{C}$ with $5 \% \mathrm{CO}_{2}$ in a humid incubator. The Cell Titer-Glo ${ }^{\circledR}$ Luminescent Cell

Viability Assay (Promega, USA) was used to determine the cytotoxicity of the hydrogel components. A standard calibration curve for the number of viable Schwann cells was plotted to define the quantitative relationship between the observed luminescence and the number of viable cells. Cells were seeded in 48 well plates with $100 \mu \mathrm{L}$ of media and $100 \mu \mathrm{L}$ of Cell Titer-Glo® reagent. After incubation for 30 minutes, $100 \mu \mathrm{L}$ of supernatant was transferred to a 96 well plate and a Synergy HT Multi-Mode Microplate Reader (Biotek, USA) was used to analyze the luminescence of the samples. To assay the effect of the HA-based and PEG-based constituents of the hydrogels, Schwann cells were seeded in 48 well plates at 2000 cells per well with $200 \mu \mathrm{L}$ of media. An additional $200 \mu \mathrm{L}$ of a solution of an appropriate quantity of HA derivatives or PEG derivatives in media was added and the cells incubated for 24 hours at $37{ }^{\circ} \mathrm{C}, 95$ $\%$ humidity, and a $\mathrm{CO}_{2}$ content of $5 \%$. Thereafter, the supernatant was removed and $100 \mu \mathrm{L}$ of fresh media and $100 \mu \mathrm{L}$ of Cell Titer-Glo® reagent was added to each well. After incubation for 30 minutes, samples were taken for measurement. A standard calibration curve for the number of viable cells was plotted to define the quantitative relationship between the observed luminescence and the number of viable cells; $n=3$.

\section{Hydrogel Swelling and Flory-Rehner Calculations}

Cylindrical gels prepared as described in section 2.5. (i.e., with diameters $9 \mathrm{~mm}$ and heights of $1.7 \mathrm{~mm}$ ) were allowed to crosslink in the hydrated state for 24 hours, and then dried until a constant dry mass $\left(M_{d}\right)$ was reached (ca. 48 hours). The gels were swelled with PBS (1 mL) in pre-weighed tubes for 24 hours. Excess PBS was removed and the swollen mass in PBS $\left(M_{\mathrm{S}}\right)$ recorded. The swelling ratio based on mass $\left(Q_{\mathrm{M}}\right)$ was then determined by dividing the swollen mass in PBS by the dry mass; $n=8$. 
$\mathrm{Q}_{\mathrm{M}}$ was determined experimentally and used to calculate the volumetric swelling ratio, $\mathrm{Q}_{\mathrm{V}}[72]$ :

$$
Q_{v}=1+\frac{\rho_{\mathrm{p}}}{\rho_{\mathrm{s}}}\left(Q_{M}-1\right)
$$

In which $\rho_{\mathrm{p}}$ is the mass-weighted average density of the dry polymers (PEG = $\left.1.126 \mathrm{~g} \mathrm{~cm}^{-3} ; \mathrm{HA}=1.229 \mathrm{~g} \mathrm{~cm}^{-3}\right)$ and $\rho_{\mathrm{S}}$ is the density of the solvent $\left(1 \mathrm{~g} \mathrm{~cm}^{-3}\right.$ for PBS $)$.

Flory-Rehner calculations allow the determination of the crosslink density and mesh size of the gels. The average molecular weight between crosslinks, $\overline{\mathrm{M}_{\mathrm{C}}}$, was calculated using a simplification of the Flory-Rehner equation [73, 74]:

$$
Q v^{\frac{5}{3}} \cong \frac{\bar{v} \overline{\mathrm{M}}_{c}}{V_{1}}\left(\frac{1}{2}-\chi\right)
$$

In this equation, $\bar{v}$ is the mass-weighted average specific volume of the dry polymers, which is the reciprocal of the density, $\rho_{\mathrm{p}}$, of the dry polymer. For PEG $\rho_{\mathrm{p}}=$ $1.126 \mathrm{~g} \mathrm{~cm}^{-3}$; and for HA $\rho_{\mathrm{p}}=1.229 \mathrm{~g} \mathrm{~cm}^{-3}$, and therefore the mass-weighted average specific volumes $\bar{v}$ of the polymers are 0.888 and $0.814 \mathrm{~cm}^{3} \mathrm{~g}^{-1}$ for PEG and HA respectively. $\overline{\mathrm{M}}_{\mathrm{C}}$ is the average molecular weight between crosslinks, $V_{1}$ is the molar volume of the solvent $\left(18 \mathrm{~cm}^{3} \mathrm{~mol}^{-1}\right.$ for water). The mass-weighted average Flory polymer-solvent interaction parameter, $\chi$, is based on the values of $\chi$ for PEG-water [75] and HA-water [Collins/birm=kinshaw APPL POYM SCI XXX], that were 0.426 and 0.473 respectively. Thereafter, the effective crosslink density, $v_{\mathrm{e}}$, was calculated as follows [76]:

$$
v_{e}=\frac{\rho_{\mathrm{p}}}{\overline{\mathrm{M}}_{c}}
$$


For HA, the following root-mean-square end-to-end distance value was previously reported [76-78]:

$$
\left(\frac{\overline{\mathrm{r}}_{O}^{2}}{2 n}\right)^{1 / 2} \cong 2.4 \mathrm{~nm}
$$

Where $n$ is the number of disaccharide repeat units for HA with a given molecular weight. For HA with a molecular weight (Mn) of ca. $2 \mathrm{MDa}, n$ is 5305, therefore:

$$
\sqrt{\overline{\mathrm{r}}_{O}^{2}}=0.1748 \sqrt{\mathrm{M}_{\mathrm{n}}}(\mathrm{nm})
$$

Combining equations (4) and (5) and substituting $M_{C}$ for $M_{n}$ gives :

$$
\sqrt{\overline{\mathrm{r}}_{O}^{2}}=0.1748 \sqrt{\overline{\mathrm{M}}_{C}} Q_{v^{\frac{1}{3}}}(\mathrm{~nm})
$$

The swollen hydrogel mesh size in PBS, $\xi$, was determined using the following equation $[76,79,80]$ :

$$
\xi=Q_{v}^{1 / 3} \sqrt{\overline{\mathrm{r}}_{o}^{2}}(\mathrm{~nm})
$$

Approximations were made in the Flory-Rehner calculations, and the values reported (e.g., $\overline{\mathrm{M}}_{C}, v_{\mathrm{e}}, \xi$ ) are therefore approximations. Nonetheless, these values are useful for making order-of-magnitude comparisons of the biologically relevant features of the gels (such as the mesh size). 


\section{Mechanical Testing}

Compressive tests were performed using an Instron Materials Testing Machine 5543 Series Single Column System (Instron, Norwood, MA) with Bluehill 2 software. Gels were allowed to crosslink in the hydrated state for 24 hours and then allowed to swell for 1 hour in PBS (1 mL). The dimensions of the cylindrical gels (height and diameter) were recorded accurately immediately before compression. Each gel was compressed to $20 \%$ of its original height at a rate of $0.05 \mathrm{~mm} \mathrm{~s}^{-1}$ using a $50 \mathrm{~N}$ load cell; $\mathrm{n}=6$. Rheological measurements were performed with a Physica MCR 101 Rheometer (Anton Paar, Ashland, VA). A humid atmosphere in the proximity of the gels was assured using wet Kimwipes. Gels were allowed to crosslink in the hydrated state for 24 hours and then allowed to swell for 1 hour in PBS $(1 \mathrm{~mL})$. For frequency sweeping tests, storage moduli G' and loss moduli G" were measured with a constant strain of $2 \%$ over a range of frequencies from 10 to $0.1 \mathrm{~Hz}$ at $21{ }^{\circ} \mathrm{C}$. For strain sweeping tests, $\mathrm{G}^{\prime}$ and G" were measured with a constant frequency of $0.1 \mathrm{~Hz}$ over a range of strains from 0.1 to $30 \%$ at $21^{\circ} \mathrm{C} ; \mathrm{n}=3$.

\section{In Vitro Degradation Studies}

Gel degradation upon exposure to hyaluronidase (10 $\mathrm{U} \mathrm{mL}^{-1}$ in PBS) was studied over 25 days. Gels were allowed to crosslink in PBS for 24 hours, swelled in PBS (1 mL) in pre-weighed eppendorf tubes for another 24 hours, and their initial mass recorded. Subsequently, gels were incubated for 24 hours at $37^{\circ} \mathrm{C}$ in $1 \mathrm{~mL}$ of the hyaluronidase solution. Samples of the supernatant solution $(50 \mu \mathrm{L})$ were taken and the uronic acid released upon degradation was quantified as described below. After removal of all of the supernatant, the mass of the gel was recorded and fresh hyaluronidase solution (1 $\mathrm{mL}$ ) was added. The masses of the gels were recorded at specific points in time and the amount of uronic acid released quantified as described below; $n=4$. 


\section{Uronic Acid Quantification Assay}

The quantity of uronic acid released upon degradation of the gels in vitro was assayed using a methodology adapted from the uronic acid carbazole reaction reported by Cesaretti and co-workers [81]. A $50 \mu \mathrm{L}$ aliquot of the supernatant from the degradation studies was mixed with $200 \mu \mathrm{L}$ of $25 \mathrm{mM}$ sodium tetraborate in sulfuric acid and heated at $100{ }^{\circ} \mathrm{C}$ for 10 minutes. After 15 minutes of cooling, $50 \mu \mathrm{L}$ of $0.125 \%$ carbazole in absolute ethanol was added to each sample and heated once more for 10 minutes. After cooling for 15 minutes, the absorbance at a wavelength of $550 \mathrm{~nm}$ was determined using a SpectraMax M3 Multi-Mode Microplate Reader. A standard calibration curve for uronic acid was plotted to define the quantitative relationship between the observed absorbance and the concentration of uronic acid; $n=4$.

\section{Cell Culture}

Hydrogels were placed in tissue culture plates and sterilized by incubation in $70 \%$ ethanol solution, followed by exposure to UV for 20 minutes. After sterilization, the hydrogels were incubated for 30 minutes under 3 mm of Dulbecco’s Modified Eagle Medium (DMEM), which was exchanged twice after 30 minute intervals. Hydrogels were subsequently incubated for 30 minutes under $3 \mathrm{~mm}$ of DMEM supplemented with $10 \%$ fetal bovine serum, $100 \mathrm{U} \mathrm{ml}^{-1}$ penicillin, $100 \mu \mathrm{g} \mathrm{ml}^{-1}$ streptomycin, $0.25 \mu \mathrm{g} \mathrm{ml}^{-1}$ amphotericin, $0.1 \mathrm{mM}$ non-essential amino acids, and $1 \mathrm{ng} \mathrm{ml}^{-1}$ basic fibroblast growth factor. Medium was aspirated and replaced prior to HMSC seeding. Cell viability before starting the experiment was determined by the Trypan Blue (Sigma, USA) exclusion method, and the measured viability exceeded $95 \%$ in all cases. HMSCs (passage 2) were seeded on the surface of the gels at 10,000 cells per $\mathrm{cm}^{2}$ under $3 \mathrm{~mm}$ of medium, and incubated at $37^{\circ} \mathrm{C}, 95 \%$ humidity, and a $\mathrm{CO}_{2}$ content of $5 \%$. After 48 hours the viability of the cells was evaluated using a LIVE/DEAD® Viability/Cytotoxicity Kit for 
mammalian cells (Molecular Probes, Eugene, OR). Briefly, the medium was removed and cells on the surface of the gels were incubated with $4 \mu \mathrm{M}$ ethidium and $2 \mu \mathrm{M}$ calcein $\mathrm{AM}$ in $\mathrm{PBS}$ for $15 \mathrm{~min}$ at $37^{\circ} \mathrm{C}$ in the dark. Live cells were stained green because of the cytoplasmic esterase activity, which results in reduction of calcein AM into fluorescent calcein, and dead cells were stained red by ethidium, which enters the cells via damaged cell membranes and becomes integrated into the DNA strands. Fluorescence images of cells were captured using a color CCD camera (Optronics ${ }^{\circledR}$ MagnaFire, Goleta, CA, USA) attached to a fluorescence microscope (IX-70; Olympus America Inc.). 
Table A1. Compositions and Properties of Hydrogels Composed of HA-ALD-1, HAALD-2, and Aminooxy-Terminated PEGs.

\begin{tabular}{|c|c|c|c|c|c|c|}
\hline Parameter & Gel 7 & Gel 8 & Gel 9 & Gel 10 & Gel 11 & Gel 12 \\
\hline $\begin{array}{l}\text { Volume ratio of stock } \\
\text { solutions } \\
\text { (PEG:HA) }\end{array}$ & $1: 10$ & $1: 15$ & $1: 20$ & $1: 10$ & $1: 15$ & $1: 20$ \\
\hline Mass of HA-ALD-1 (mg) & 1.4 & 1.5 & 1.4 & 0 & 0 & 0 \\
\hline Mass of HA-ALD-2 (mg) & 0 & 0 & 0 & 1.4 & 1.5 & 1.4 \\
\hline $\begin{array}{l}\text { Mass of } 4 \text { kDa PEG- } \\
\mathrm{ONH}_{2} \text { (mg) }\end{array}$ & 7.535 & 5.382 & 3.767 & 7.535 & 5.382 & 3.767 \\
\hline $\begin{array}{l}\text { Compressive modulus, E } \\
(\mathrm{Pa})\end{array}$ & $\begin{array}{l}2360 \pm \\
590\end{array}$ & $\begin{array}{l}2100 \pm \\
750\end{array}$ & $\begin{array}{l}1760 \pm \\
580\end{array}$ & $\begin{array}{l}1470 \pm \\
190\end{array}$ & $\begin{array}{l}750 \pm \\
130\end{array}$ & $\begin{array}{l}1470 \pm \\
100\end{array}$ \\
\hline
\end{tabular}

Masses reported are dissolved in PBS $(150 \mu \mathrm{L})$. Compressive modulus (CM). 
Table A2. Compositions of Hydrogels Composed of HA-ALD-24, AminooxyTerminated PEGs and Col-1.

\begin{tabular}{|c|c|c|c|c|c|}
\hline Figure & Gel \# & $\begin{array}{l}\text { Mass of } \\
\text { HA-ALD-24 } \\
\text { (mg) }\end{array}$ & $\begin{array}{l}\text { Mass of } \\
2 \mathrm{kDa} \text { PEG-ONH} 2 \\
(\mathrm{mg})\end{array}$ & $\begin{array}{l}\text { Mass of } \\
4 \mathrm{kDa} \text { PEG-ONH} 2 \\
(\mathrm{mg})\end{array}$ & $\begin{array}{l}\text { Mass of Col-1 } \\
(\mu \mathrm{g})\end{array}$ \\
\hline $5 \mathrm{~A}$ & 13 & 1.40 & 3.28 & 0.00 & 7.5 \\
\hline $5 B$ & 14 & 1.40 & 3.28 & 0.00 & 15 \\
\hline $5 C$ & 15 & 1.40 & 3.28 & 0.00 & 30 \\
\hline $5 \mathrm{D}$ & 16 & 1.50 & 2.34 & 0.00 & 7.5 \\
\hline $5 \mathrm{E}$ & 17 & 1.50 & 2.34 & 0.00 & 15 \\
\hline $5 \mathrm{~F}$ & 18 & 1.50 & 2.34 & 0.00 & 30 \\
\hline $5 G$ & 19 & 1.40 & 1.64 & 0.00 & 7.5 \\
\hline $5 \mathrm{H}$ & 20 & 1.40 & 1.64 & 0.00 & 15 \\
\hline $5 \mathrm{I}$ & 21 & 1.40 & 1.64 & 0.00 & 30 \\
\hline $5 \mathrm{~J}$ & 22 & 1.40 & 0.00 & 7.54 & 7.5 \\
\hline $5 \mathrm{~K}$ & 23 & 1.40 & 0.00 & 7.54 & 15 \\
\hline $5 \mathrm{~L}$ & 24 & 1.40 & 0.00 & 7.54 & 30 \\
\hline $5 \mathrm{M}$ & 25 & 1.50 & 0.00 & 5.38 & 7.5 \\
\hline $5 \mathrm{~N}$ & 26 & 1.50 & 0.00 & 5.38 & 15 \\
\hline 50 & 27 & 1.50 & 0.00 & 5.38 & 30 \\
\hline $5 P$ & 28 & 1.40 & 0.00 & 3.77 & 7.5 \\
\hline $5 Q$ & 29 & 1.40 & 0.00 & 3.77 & 15 \\
\hline $5 \mathrm{R}$ & 30 & 1.40 & 0.00 & 3.77 & 30 \\
\hline
\end{tabular}

Masses reported are dissolved in PBS $(150 \mu \mathrm{L})$. 

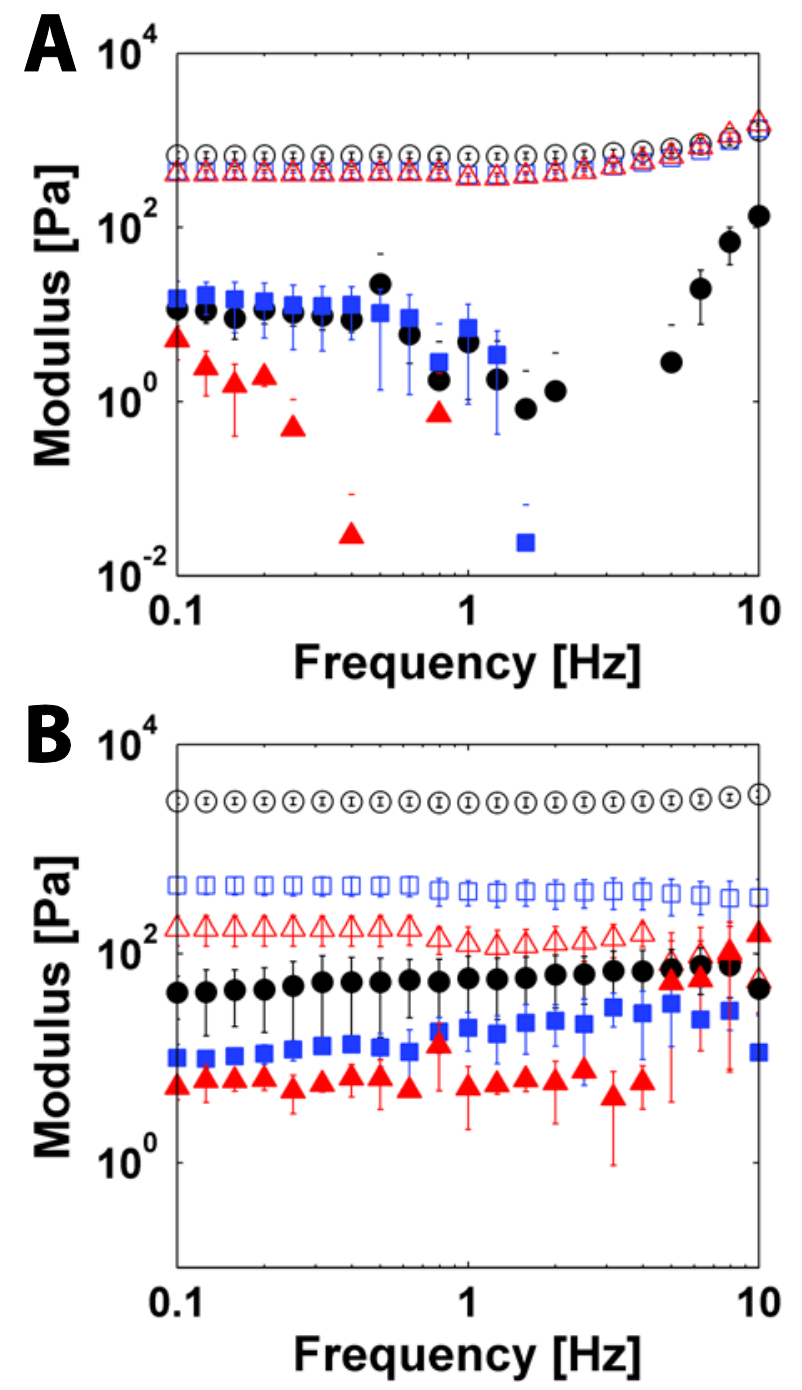

Figure A1. Response of the gels to shear stress as assessed via rheology. Shear modulus, G', hollow shapes. Loss modulus, G’', filled shapes. A) HA-ALD-24 and PEG2k. Black circles: gel 1. Blue squares: gel 2. Red triangles: gel 3. B) HA-ALD-24 and PEG4k. Black circles: gel 4. Blue squares: gel 5. Red triangles: gel 6. 


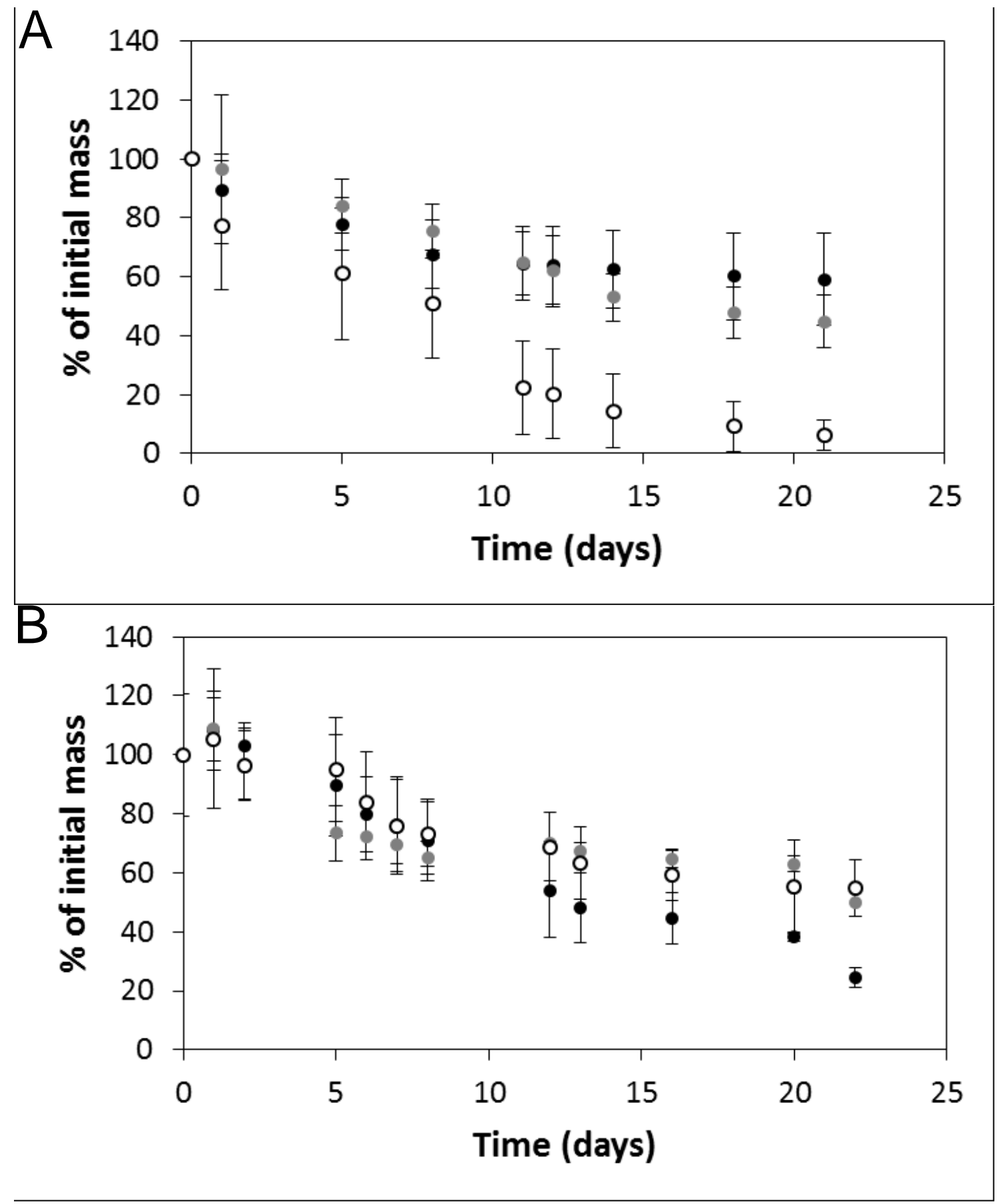

Figure A2. The results of gel degradation assays upon exposure of gels 7-12 to hyaluronidase (10 U/mL in PBS). A) Mass loss assay for gels composed of HA-ALD-1 and aminooxy-terminated PEG4k. Gel 7, black circles. Gel 8, grey circles. Gel 9, white circles with black edges. B) Mass loss assay for gels composed of HA-ALD-2 and aminooxy-terminated PEG4k. Gel 10, black circles. Gel 11, grey circles. Gel 12, white circles with black edges. 

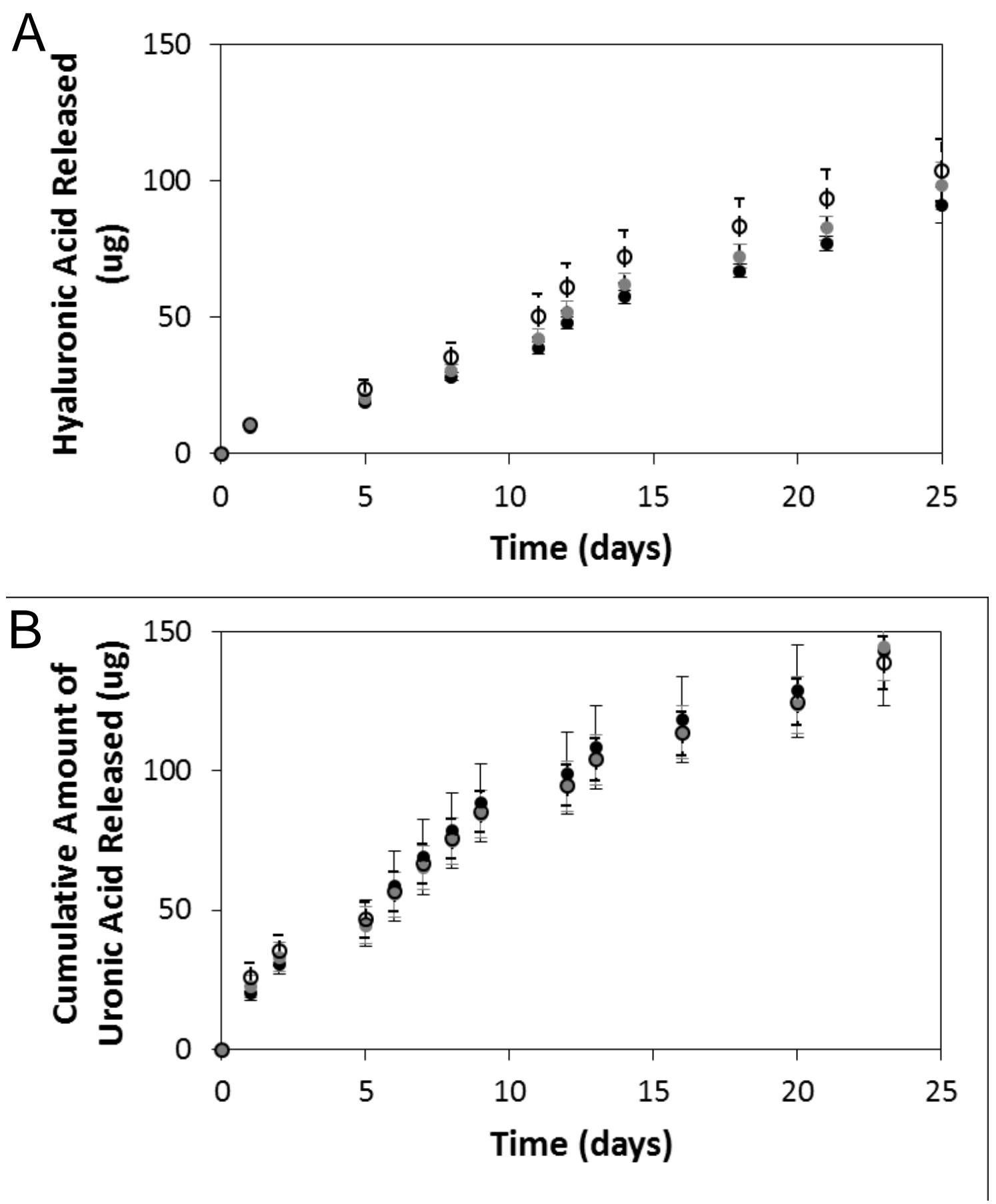

Figure A3. The results of gel degradation assays upon exposure of gels 7-12 to hyaluronidase (10 U/mL in PBS). A) Uronic acid release assay for gels composed of HA-ALD-1 and aminooxy-terminated PEG4k. Gel 7, black circles. Gel 8, grey circles. Gel 9, white circles with black edges. B) Uronic acid release assay for gels composed of HA-ALD-2 and aminooxy-terminated PEG4k. Gel 10, black circles. Gel 11, grey circles. Gel 12, white circles with black edges. 